\title{
The lived city: everyday experiences, urban scenarios, and topological networks
}

\author{
Alicia Lindón \\ Departamento de Sociología, Universidad Autónoma Metropolitana, \\ Campus Iztapalapa, Mexico City, Mexico \\ Correspondence: Alicia Lindón (alicia.lindon@gmail.com)
}

Received: 16 May 2018 - Revised: 7 January 2019 - Accepted: 24 January 2019 - Published: 7 February 2019

\begin{abstract}
The general subject of this text is the contemporary city, understood as a lived territory: it develops a theoretical-methodological approach to the sociospatial construction of urban territory that integrates both the material and the nonmaterial.

The sociospatial construction of the lived city is approached via an articulated set of analytical levels. Accordingly, the first part presents the level of the spatial practices and the urban imaginaries that accompany them. The second part integrates the incorporated affectivity that acts and territorializes itself in the everyday life of the city. The third part considers urban scenarios as situational articulations of the subjects of the two previous parts. Individual topological networks are then incorporated as sequences of urban scenarios that integrate the subjects' biography, leading on to the crisscrossing of different topological networks in an approximation of the lived city in all its fragmented, dense, and fluid complexity.
\end{abstract}

\section{Introduction}

The general subject of this text is the contemporary city, understood as a lived territory from day to day (Di Méo, 1991, 2006). More specifically, it develops a theoreticalmethodological approach - rooted in different levels of analysis - to the sociospatial construction of urban territory that integrates both materiality (fixed and lived) and nonmateriality in an experiential viewpoint revolving around the constant flux of everyday life.

Urban studies have developed analytical schemes that focus on spatial forms, and these have proved extremely effective for understanding various aspects of the materiality of cities, but the notion that a city is more than just materiality poses a significant challenge in this field. In this context, this text is based on a dual premise: on the one hand, nonmaterial elements are indissociably intertwined with the spatial forms with which they coexist, even though they are often overlooked in urban analysis; on the other hand, both the city and urban life are being ceaselessly configured by the flow of everyday life - they are unstable phases of social living. Thus, the main aim of this text is to provide a multidimensional but fully grounded approach to the sociospatial con- struction of the lived city as a lived territory (Lindón, 2015). This territory can unfurl on various spatial scales, and here it is considered as a day-to-day or lived territory that "is set in the places of our experience, impregnated with our routines and attachments" (Di Méo, 2008:16). It is conceived multidimensionally, in keeping with Di Méo's (1999) perspective, in material, social, political, and symbolic terms. In material terms, territory is made up of defined spatial forms and has discernable frontiers. In social terms, territory expresses subjects' adherence to social groups and is therefore linked to collective identity and can become an action system that exerts an influence on social relationships. In political terms, it expresses forms of spatial control characteristics of a social group, thereby ensuring the latter's reproduction and durability. In this respect, territory is also connected to spatial appropriation. Territory also has a symbolic dimension because its elements are endowed with meanings and values that contribute to collective identities. It should also be noted that "territory gathers together and associates places that are identified by means of the practices undertaken therein" (Di Méo and Buleón, 2005:87). 
This approach articulates three related phenomena that interconnect subjects with urban space, as well as representing expressions of territoriality. Firstly, there is dwelling, the holistic and existential experience of being in a certain place. Secondly, there is the material configuration or assemblage of the places that subjects create every day through their dwelling. This implies the elimination of certain spatial forms, as well as specific objects, and the integration of others, in accordance with the subject's lifestyle and the practices that comprise it. And, thirdly, there is the transformation of spatial forms into subjects' living spaces. In other words, the sociospatial construction of the city as a lived territory is made possible by territoriality, as are the multidimensional relationships of the subject with his or her living spaces, where at least three levels come into play: the existential level of being on the land; the subject's relationship with the material environment; and the patterns of meaning that are woven with respect to this environment, its exteriority, and the alterity that it integrates (Raffestin, 1986).

These three phenomena must be considered in the light of the biographies of the city's inhabitants, which can in turn be understood as stocks of experiences that accumulate spatial insights within people that allow them to tackle new urban experiences. These biographies merge subjects' spatial experiences, and this amalgam constructs the lived territory. At the same time, these spatial experiences give form to every life, which is always territorialized. This constitutes a sociospatial construction of urban territory along biographical and experiential lines: the sociospatial construction of urban territory is a collective multidimensional process to which the various inhabitants bring fragments that correspond with their own biographies (which can be considered as assemblages of infinite spatial experiences). The inhabitants therefore identify with some fragments of the territory constructed in everyday experiences of the urban setting but not so much with others. In short, biographies interlink with others and become territorialized. This interconnection forms part of the social dimension of the territory in play in this process. Thus, the sociospatial construction of the urban territory is a process that is always in progress because the lives that comprise it are always in flux.

The second characteristic of the sociospatial construction of urban territory is the way that it becomes embedded in the discourse of its inhabitants (Lindón, 2015): the discourse gives it form. The fragments of biographies that are being narrated are related to specific lived circumstances. These links, with their array of fragments from past experience, mean that the spoken city contains information that forms part of these biographies and therefore refers to places associated with the speakers' everyday lives. However, the articulation of urban experiences (into a narrative) allows them to circulate beyond the person who lived through them, and this circulation, in its turn, allows these discourses to impinge on other people's everyday practices. An inhabitant's lived experience thus becomes social. It circulates and forms part of the ever-flowing collective process of sociospatial construction lived by subjects in countless interactions of various kinds (cooperation, disagreement, etc.).

This theoretical-methodological proposal approaches the process of sociospatial construction of the lived city as an ensemble comprised of different analytical levels. Accordingly, the first part of the text deals with the level of spatial practices and their associated urban imaginaries. The second part draws in the incorporated affectivity that acts and is territorialized in the city's everyday life. The third part considers urban scenarios as situational articulations derived from the situations developed in the two previous sections. Following this, a consideration of the individual topological networks as sequences of urban scenarios that integrate subjects' biographies and the subsequent crisscrossing of different topological networks, which provide an approximation of the complexity of the lived city in all its dense, fluid fragmentation is presented. The text closes with some reflections, but these are not intended to bring the debate to a close. These sections analyze territory's constituent dimensions: practices and imaginaries reveal the social and symbolic dimensions that construct the urban territory. Affectivities integrate these dimensions with the political dimension, with appropriation, and urban territorialities. Urban scenarios explore the situational configuration of places in the city by intertwining materialities, practices, imaginaries, and affectivities. Topological networks make it possible to move from the situational singularity of a particular place to the ensemble of places belonging to each biography. This explains why places that are far removed and distinct from each other can be connected by the biographies of the people living in them. These connections bring with them an intermeshing of meanings. Ultimately, the crisscrossing of topological networks involving various subjects constructs a city as a lived territory integrated by networks from different places.

\section{Everyday spatial practices and urban imaginaries}

The sociospatial construction of the city as a lived territory revolves around one basic nucleus: the spatial practices of its inhabitants - in other words, their everyday actions - which unfold in specific places, and their various forms of territorialization. Spatial practices form part of the array of their small worlds, which can be linked to the domestic sphere, a workplace, an educational establishment, or to shopping, leisure, or other everyday activities, depending on the subjects under consideration. They constitute the solid nucleus of a territory's social dimension.

Simonsen (2007) has emphatically stressed that nothing in the social world exists prior to practices - no awareness, no ideas, no meanings, no structures, no mechanisms, no discourses, no networks, no pacts. Werlen (1992) has also highlighted the centrality of social action in relation to space, and he even called his theory the "geography of practices". Lus- 
sault and Stock (2010) have similarly dwelled on the centrality of practices and their practice-based approach is known as the pragmatics of space.

Any spatial perspective primarily focused on practices thereby acknowledges that these always have some meaning. People develop particular practices because they are seeking something through them. In other words, there are motives behind their actions, and the sense of these actions is configured during the development of the practice. This expresses the symbolic dimension of territory.

An examination of the sense of everyday practices from a spatial perspective brings to light two issues that are relevant to our approach. On the one hand, the meanings acquired by practices as they are being undertaken tend to be transferred to the places in which these practices are rooted. This enables places to also acquire density. Buttimer (1976) was already pointing out that people were imbuing places with intentions, values, and memory through their everyday practices. On the other hand, the motivation to perform a particular practice, or the meaning bestowed on it, is often derived from the place associated with this practice. So, practices always spring from meshes of meaning that reactivate themselves and are sometimes reconfigured: the places in which practical life unfolds bestow meaning on local tasks, while practices reconstruct the meaning of places. Along these lines, Adams et al. (2001) suggest that it is within these dynamics that places acquire texture, and this gives rise to a territory's processes of symbolization. Similarly, it has been conjectured that there are places of memory - whether individual or collective - that result from a place's capacity to remember events that occurred there. And a place's memory endows it with a particular character, making it a vehicle for a specific meaning.

Our understanding of the city's processes of sociospatial construction is not exclusively confined to an analysis of spatialized everyday practices and their meanings. This level of spatial pragmatics needs to be considered alongside that of urban imaginaries (Silva, 1992). Although the meanings of spatialized practices belong to the field of spatial subjectivity, just as imaginaries do, they should not be superimposed on each other: these meanings give sense to various specific practices and show the motivation behind them, while imaginaries are more wide-ranging recipients of sense that embrace numerous practices and occurrences that lead to certain outcomes. Urban imaginaries are psycho-perceptive processes, motivated by desire, that generate ways of understanding the world, ways of being and behaving, and collective actions. They are embodied or incorporated into various public objects, such as texts, images, art, and architecture (Silva, 2006). Silva's urban imaginaries enrich this approach because they provide symbolization processes for the lived city: on the one hand, this is because the materialization processes of its inhabitants' images, which were originally immaterial and internal, contribute to the collective manufacturing of the city (as in the case of graffiti). On the other hand, this materialization of images in the city means that something that was internal to a subject becomes public and is interpreted by others, and it thus acquires further meanings. Finally, the fragments of a city into which its inhabitants integrate materialities that become subject to successive interpretations are themselves also subject to appropriation by other people in their own everyday lives.

On the broad spectrum of social imaginaries, urban imaginaries in particular are subjective, fantastical tapestries of the city and urban life. They may concern the city as a whole or focus on specific aspects, agents, or places within the city. This view highlights the mesh woven by the imagination from various elements taken from the shared meaning and it therefore anticipates possible means of transformation. These elements are practices, sometimes in the form of rituals imbued with values, desires, intentions, events, restrictions, and prohibitions, and sometimes in the form of objects, places, and subjects. One significant feature is that these subjective, spatialized tapestries adopted by the inhabitants of a place are not always derived from objects, subjects, events, or practices that unfold in situ. Sometimes they draw on phenomena and series of practices that did occur in this place but at another point in history, but they can also spring from facts, objects, subjects, and events that evolved in other places. To put it another way, one characteristic of social imaginaries, and of urban imaginaries in particular, is that they come from everyday experiences far removed in time and space. This makes their "nonrepresentational" nature crucial. As Castoriadis (1987) has suggested, imaginaries can evoke objects, subjects, places, or situations that are absent for whatever reason - maybe because they were never present, or because they were previously present and then ceased to be so (Lindón, 2008). They are capable of moving through time and space or of migrating from one city to another or from one country to another. This is what sets them apart from the meaning of a practice, as this sense is always configured during the unfolding of the practice in question. The nonrepresentational nature of imaginaries posited by Castoriadis furthers our understanding of the process of sociospatial construction of the lived city because it throws light on the role played by fantasy in this process.

This near ubiquity that is characteristic of urban imaginaries may not represent any local phenomenon but may paradoxically model the everyday practices of local subjects, bestowing intelligibility on the city through their capacity to configure instruments of perception and understanding of the urban reality and distribute them among the city's inhabitants (Lindón, 2008:40). Urban imaginaries therefore induce some practices or inhibit others by putting patterns of perceiving and understanding the world into social circulation: they are actants.

Sometimes urban imaginaries are projective urban fantasies that look firmly to the future, while on other occasions they stand as retrospective urban fantasies. In the latter case, they are the result of complex articulations between 
the past and the future, which imbues it with fantasy. In both cases, urban imaginaries can be radical or derived Castoriadis (1987). Radical imaginaries are the product of individuals' creative imagination and induce social change, whereas derived imaginaries result from the takeover by society of individuals' imaginations and they therefore encourage social reproduction. These two types of urban imaginaries are sometimes referred to as imaginaries of resistance and domination (Lindón, 2008).

These subjective tapestries, known as urban imaginaries, are woven into the symbolic structures of societies and emerge to manifest their capacity to configure action in everyday territory. Thus, the concept of the lived city's sociospatial construction via spatialized and meaningful everyday practices immersed in various urban imaginaries "dignifies everyday territory" through particular forms of a certain historicity not unconnected to far-reaching processes that may produce new social forms or reproduce existing ones. Thus, everyday practices and their meanings join forces with urban imaginaries to constitute the three-faceted bedrock of the city's sociospatial construction in a lived territory.

\section{Incorporated and territorializing affectivity}

The practices of everyday life - with all the meanings that accompany them and the imaginaries into which they can be interwoven - are crucial to any understanding of the city as lived territory. However, consideration of the incorporated affectivity that accompanies practices opens up a better approximation of the urban phenomenon itself. Something that affects is therefore primarily something that influences the self and is materialized in the body, but it can also refer to something that exerts an influence on other people through a degree of affect present in our body.

According to the Deleuzian perspective of Clough (2008), "affect" refers to the body's capacity to affect and be affected, and this embraces sensitivity, the emotional domain, and life itself. This does not mean, however, that affectivity is synonymous with emotions, although it is difficult to untangle them from each other. Some authors have attempted to differentiate between them. Thrift (2008), for example, integrates a material focus on affects, due to their corporeal nature, while establishing emotions on the plane of the subjective experience of affect. In contrast, Anderson (2009) considers that there is nothing to be gained, in analytical terms, from differentiating between affects and emotions and instead opts for an integrated, holistic approach. His concept of "affective atmospheres" integrates the material and the subjective, affects and emotions, "presence and absence, materiality and ideality, definite and indefinite, singularity and generality" (Anderson, 2009:77). Emotions - which are always manifested in the body - imply body movement, which is derived from alterations in the blood flow in reaction to spatial experiences. "Emotions are an adaptive biological strategy to eval- uate our environment; using them, the subject evaluates the world in which she lives in an immediate, prerational way, in a way that is simply lived and not thought, thereby encouraging a response that is also immediate, fast, unpremeditated, automatic" (Pintos Peñaranda, 2010:149).

Any deciphering of the urban context is more enriched by considering the relationship between affectivities or emotions and corporeity than by considering emotions in themselves. And in this respect it is worth remembering the approach of Merleau-Ponty (1962), who observed that things (the world external to the human being) are embodied within us by our perception. They are not therefore a pure perceived object - external and recognized - but are rooted in our body, articulated to the very structure of our perception. Outside and inside, exterior and interior, exist within a relationship of reciprocal implication. It is possible to draw from his reflections the idea of the external embodied in the subject, inscribed in the body. If this conception is valid in relation to the external world of things, it can be even more applicable to affectivity, which is essentially derived from the sphere of emotions and sensations.

By applying a spatial emphasis and following the nonrepresentational theories (NRTs) (Thrift, 2008; Anderson and Harrison, 2010) - initially called "theories of practices" (Thrift, 1999) - affect can be conceived as a nondiscursive scenic sensation that moves from one body to another (Thrift, 2008). The framing of affect in scenic terms alludes to specific places in which something is at play between the actors. At the same time, the scenic elements also refer to the situational and circumstantial nature of affect and emotions. The NRTs emphasize the nondiscursive nature of affect by stressing that the latter precedes the awareness that is necessarily implicated in language. In the approach followed herein, the nondiscursive tendency of affect is seen in a pre-discursive light, based on the assumption that affectivity appears prior to its formalization in a discourse, but once it becomes apparent it is then also put into words.

Another key aspect of this conception of affectivity is the way it circulates between bodies in a particular space-time: affectivity is social because it goes beyond the individual and moves from one body to another in the proximity afforded by places in the city. The circulation of affectivity between bodies generates types of performativities or dramatizations of the social element (Turner, 1974) in play in every situation, and these are ephemeral materializations of that affectivity (Pile, 1996).

In densely inhabited public urban space, one can often observe various subjects, at a given time and in a given place, experiencing and bodily communicating something similar in the face of a particular occurrence, even though they do not know each other. These affectivities are prompted by something external to the subjects - a local occurrence - that affects them and thus becomes incorporated (or inscribed) in their bodies. This gives rise to a particular body movement. Furthermore, this affectivity circulates from one sub- 
ject to another, triggering a movement between those subjects close to the event. Examples of this include performativities of constriction in the face of an unforeseen phenomenon, those of distancing (diastemic performativities), and those of protection and self-protection. In performativities of constriction, bodies seem to become smaller than they were prior to the event that is occurring. Diastemic performativities, or those involving distancing, express an almost instantaneous impulse to move away from a particular hub of an occurrence, even when physical separation is curtailed by the place's material conditions. Performativities of protection and self-protection, meanwhile, try to reduce the body's visibility and/or exposure by taking advantage of objects or other bodies, or the place's spatial forms, or corporeity itself. Another example of affectivity that constructs space while also being constructed by a place is the dramatization of different social distances in the various urban spaces in which encounters occur between alterities far removed from each other socially and culturally.

Affectivities inherently make and unmake the city's places at all times because they configure the latter according to the ways they feel in them and their ways of behaving; in short, according to the mise en scène. Affectivities therefore materialize themselves in performativities and practices. So, embodied affectivity "happens" and is territorialized in accordance with its dispositions or ways of acting.

One characteristic feature of these affectivities is the simultaneity between the production of the pre-discursive emotion sensation and its movement, circulation between bodies, and territorialization. This simultaneity is usually identified with enacted expression, meaning something that cannot be separated into parts or phases or into what comes before and what comes after, on account of this very simultaneity and multidimensionality. However, in terms of the sequential order inevitably dictated by written expression, affectivity is said to emerge, circulate between bodies and become territorialized, but the very nature of the phenomenon implies that everything which is forced by the limitations of grammar into a sequence in fact occurs at the same time.

It is thus more appropriate to insert "affectivity, performativity, and territorialization" into the constructivist approach now holding sway than affectivity alone, as these three dimensions operate simultaneously. In this unending process, the "body-subjects" (Seamon, 1980) inhabiting the city are affected by something external, in which action - in the form of bodily dramatization - emerges in and with the lived territory and with the other people who cohabit it at that moment. Accordingly, the construction process of a lived territory with specific features is energized, even when it is ephemeral. In this way, with the aid of corporeity (the body and what it expresses in each situation) an individual appropriates the space and the time impinging on him or her and transforms it, giving it a certain value and configuring territoriality as a specific, situated, and dynamic link.
This circumstance does not make every affectivity, dramatization, and territorialization unique, as whatever is in play and its defining patterns, and even performativity itself, tend to reproduce themselves (albeit not in identical terms) in various places and moments of time. Nevertheless, every dramatization can possess a degree of singularity, as a particular expression of the urban situation in question, but it cannot claim to be unique. In other words, singularity is derived from the situational nature of affectivities, corporeities, and territorializations.

\section{Urban scenarios}

Everyday practices and their meanings, and the urban imaginaries that arise within them, are inscribed, along with affectivities and performativities, in the everyday to-and-fro and its rhythms, as well as in the various places that constitute the city's topological surface. The complex mesh of urban territory can therefore be partially understood in empirical terms as spatial-temporal fragments, referred to herein as urban scenarios.

The lived city's urban scenarios are units of space-time that can be fleeting or more prolonged and they can reoccur with a degree of cyclical frequency or be one-offs; sometimes they are found in places that are highly visible, at other times their visibility is partial and restricted. They feature subjects who inhabit the city (sometimes known to each other but often not), perform individual or collective practices, and put into play knowledge about what to do, how to interpret the other people who form part of the situation, and how to behave, and this gives rise to proxemics and diastemics (Lindón, 2013), whether physical or social-cultural, in which everybody expects something to happen. In a strict sense, all urban scenarios are unique. Nevertheless, it is notable that similar scenarios repeat themselves constantly, despite changes in the actors and the settings and fragments of time in which they occur. In any case, urban scenarios lead to an understanding of the city and urban life as a continuous process of doing and undoing - and urban scenarios are one of the emblematic expressions of the dynamics of the urban movement in vitalist terms. However, this view of urban scenarios has a component inspired by Goffman that embraces discursive elements, and it also integrates instability and contingency, which are more closely associated with the affectivities mentioned above. Urban scenarios are essentially dynamic, relational, and situational. Urban scenarios demonstrate that social frameworks emerge and are negotiated situationally within urban life (Goffman, 2006), and it is the tension between what is reproduced (reiterated) and what is transformed that gives rise to the constant sociospatial construction of the lived city.

Urban scenarios are dense fragments of the lived city and the latter's vitalist movement flows through them. The city is made up of infinite scenarios at every moment, and every 
scenario is a particular form of the everyday flux that materializes the lived city. The other side of this richness is the inevitable fugacity inherent to these urban scenarios. Fugacity does not diminish their contents, however, as they construct and deconstruct themselves to the rhythm of the city. This very temporariness means that only minutes after one scenario has been brought to life it goes on to form part of other scenarios. All this gives expression to the dynamic nature of urban scenarios.

Scenarios are also relational because they always involve a meeting of alterities, giving rise to various degrees of social interaction. At the same time, scenarios give rise to relationships between subjects and the spatial forms intrinsic to the place (materiality). One such relationship can be the appropriation of these spatial forms by actors, in material or symbolic terms. Sometimes a scenario's relational nature can come to life in subjects' relationship with a strong, enduring sense of a place derived from a scenario's spatial grounding, as when, for example, urban scenarios are constructed on specific memorial sites.

In short, another distinguishing feature of urban scenarios is their relational nature, but their situational characteristics are equally intrinsic. Situation offers an enlightening approach to everyday urban life because it refers to actors' fragment of space-time. According to the theories of situated cognition, individuals who act are inextricably linked to the social world (Lave, 1997): urban scenarios provide the setting for the emergence and reconstruction of the social worlds of action. The situated condition is not exclusively derived from the scenario as regards a place's specific location but rather from what is put in play there, from the framing of the scenario, and from the expectations and affectivities that circulate and materialize themselves in specific performativities. Anderson posits a concept similar to this situated nature of the scenario: "diffuse, vague, affective atmospheres". This concept embraces both the materiality of corporeity and the subjectivity associated with that corporeity, i.e., affects and emotions (Anderson, 2009; Michels, 2015). Urban scenarios and their situated condition are not affective atmospheres in Anderson's sense but they can be considered as being present in every scenario as an expression of its situated nature and the affectivities territorialized therein, and they endow it with a particular tone.

For all the above reasons, urban scenarios have considerable methodological potential, thanks to their dynamic, relational, and situated nature. The scenarios provide a more wide-ranging view of the lived city.

\section{From territorialized biographies to the lived city: topological networks}

The approach presented herein is further enriched by the integration of another level in which the sequences of urban scenarios in which a subject has participated over the course of his or her biography is taken into account. Thus, urban scenarios cease to be demarcated as spatial-temporal situations closed in on themselves and grow into situations in which all the actors involved connect - by comparing and contrasting similarities and differences - with other situations lived in other moments of their biographical trajectory. Accordingly, each actor's biography is constructed via a chain of transmission of knowledge, behavior patterns, and senses that combine scenarios lived on an individual basis in both the past and present. The memories and recreations of other places lived by a subject can emerge in a scenario in which he or she participates in the present and thus contributes to its current sociospatial construction, thereby allowing scenarios to acquire density and interconnect with other ones.

From the perspective of the biography of every actor involved in these situations, this means that he or she is participating in a scenario, from one minute to the next, and every one of these scenarios is associated with different exteriorities, alterities, codes, and behavior patterns. This leads to the configuration of what could be called a particular subject's topological network: this consists of the incommensurable totality of the places where that subject goes and puts their self into play, situationally. The places that comprise such a topological network bear the marks of the people who have formed part of these places and the scenarios that unfolded there, as well as their appropriations (whether predominantly material or symbolic) by each subject, how they have been named, and the narratives that they have given rise to from the biographies of the people who have put down roots there.

A subject's topological network outlines the contours of his or her world, but this world has movable borders because topological networks are always extensive and retractile (Di Méo, 1991): at some points in a subject's biography, the topological networks stretch out to more places, sometimes going beyond their spatial center or triggering a displacement of the spatial biocenters. Meanwhile, at other points in the subject's biography, the topological networks are restricted, with a resultant reduction in places, activities, and also alterities. This property of both extension and retraction is linked to each subject's everyday flow, which changes over the course of his or her biographical trajectory.

As Pred $(1977,1981)$ has pointed out, encounters between different individuals occur in the context of projects (institutionalized to a greater or lesser degree) that bring them together, connect them, or simply put them in close physical proximity. People's topographical networks (their places and the urban scenarios in which they participate) can thus acquire greater depth if there is an integration of the institutionalized projects through which the subject becomes part of each scenario. The integration of an individual's projects therefore provides keys to understanding his or her practices and behavior within a scenario.

Each subject's topological networks (with the multidimensionality proper to them) are derived from the dynamics of the city's sociospatial construction process. But the city as 
lived territory is the result of the contours and texture of the intersections of one inhabitant's topological networks with those of others. This allows us to move toward seeing the lived city as a myriad of interconnected topological networks that provide a setting for the circulation of affectivities, meanings and memories of places, and urban imaginaries, along with spatial knowledge and conventions for acting within them, or disputes and conflicts about places and the actions performed in them.

The crisscrossing of the various inhabitants' topological networks traces - in an unstable manner - the texture of the lived city: in some hotspots the lived city is extremely bulky, due to the multiple scenarios and biographies interconnecting therein, while other places present simpler textures, because the spatial experiences, scenarios, and biographies territorialized therein have been fewer or more fleeting or less dense. In a similar manner, some places present an infinite number of connections because they are poly-inhabited, while others have only a few connections.

The crisscrossing of the topological networks of a city's inhabitants can be reflected in the diagrams used in almost every global city over the last 2 decades to represent connectivity networks (particularly those of a digital nature) in the context of the transition toward smart cities ("Cities 4.0"). There is indeed a link between the two approaches, although the topographical networks proposed herein are centered on the experience of inhabiting these places and not on technology, and so they are not the same. Nevertheless, these multiple connectivities intrinsic to Cities 4.0 do have repercussions on the spatial experience of a city as lived by people, and to some extent they are reconfiguring its inhabitants' topological networks, particularly as regards the definition of "near" and "far". The interaction between a city's networks of digital connectivity and people's topological networks is a field of study that needs to be analyzed in depth. The difference between the space of representations and lived space posited by Lefebvre (1974) may possibly provide us with a means of analyzing the relationship between the networks of digital connectivity (a certain syntony with the space of representations) and citizens' topological networks (closer to lived space).

\section{Conclusions}

The sociospatial construction of the lived city enhances subjects' relationships with their everyday territories. This implies that the focus is not on the inhabitant or the territory but on the link between the two - in other words, on the territoriality. Similarly, this perspective has not been constructed from an aerial view from outside the territory but rather through the prism of territoriality itself, seen as the subject's multidimensional relationship with his or her lived territories.
The successive levels integrated into this premise have not been conceived as a cut-and-dried scheme, but rather as a group of analytical fields which, although indispensable to any deciphering of the lived city, could also be complemented by still more jigsaw pieces. These analytical levels go beyond the notion of scale, as this concept is closely associated with materiality and its measurable dimensions. However, the dimensions under consideration here overwhelm any perspective of scale, although the experiential scale would have the most affinity with the perspective presented herein.

Thus, one objective of this text has been the search for angles from which the urban situation can be observed free from the immovable, reifying certainties that have become so common in studies of the city of homo dormiens, as regards the predominance of given spatial forms and locations. Here, the city is presented as the handiwork of its inhabitants, integrating the social sphere into the meshes of meanings and imaginaries that move subjects, and also into the projects (institutionalized or otherwise) in which subjects unfurl their daily practices.

Any attempt to understand the city and the urban situation from vitalist viewpoints, focusing on everyday life and the subjects who inhabit cities, implicitly acknowledges the impossibility of knowing a city over its entire extension (a premise that has been widely accepted). Such knowledge could only be acquired through a series of successive reductions, particularly the reduction of urban space to the locations of people and objects, even when it is recognized that these are the end result of historical processes.

This approach involves sidelining the city in its full extension in order to hone in on dense fragments of the urban situation that are unstable and ever-changing, although they are not isolated, as they are interconnected via the dwelling of territorialized subjects. These urban fragments do not have to be adjacent or spatially continuous. Thus, the concept of the city presented above forsakes both chorological and topographical approaches in order to explore topological viewpoints. This therefore highlights the concept of urban territory inhabited by mobile subjects, who appropriate and dispute fragments of that space to make them their own, to mark them, create narratives from them, inscribe their own biographies on them, and sometimes then abandon them to inhabit other places. These mobile subjects are not only the homo faber of the city but also body-subjects and sense-subjects faced with alterities (some sought, others neither sought nor desired), who inscribe biographical events, dreams, fantasies, fears, rejections, values, ideas, and images into the places of their life: the sociospatial construction of the city is undertaken within the everyday by the subject-inhabitant.

Urban scenarios are constituted on a necessarily analytical level, since all of the above occurs in fragments of spacetime in which something is put into play and everything that is corporally done, felt, and performatized here is situated 
both in that small lifeworld and also in the social world of each subject involved therein.

The subsequent incorporation of individual topological networks allows us to make visible the depth of the present: the moment in time proper to an ephemeral urban scenario constitutes a dense present because it integrates the various pasts of each subject involved in the scenario. How does it do this? By virtue of the spatial memory and knowledge that have bestowed on the subject a stock of ways to interpret what is going on, and of possible actions in the face of what is being played out. In other words, each new space-time situation in the city does not occur - and is not consumed - solely within the course of its ephemeral duration. Prior to that, each of these situations has already integrated many moments from the past, as well as the knowledge that these have bestowed on the subject. Topological networks are the mechanisms by which some places in the city reproduce the characteristics of - or instead differentiate themselves from - other places. Topological networks unfurl via canals along which the sense of a place can travel: so, the sense attributed to one place - as, for example, a territory of safety and protection - is attributed to another one, despite a physical distance between the two. This occurs because what is lived by a subject at a certain point in his or her biography is remembered and activated later on, maybe in a distant place. Thus, urban scenarios, which could seem excessively situational, feed on the biographical depth of each participant in the scenario.

The crisscrossing of the topological networks of the various subjects that coincide in a scenario provide glimpses of the origins of the complexity of each moment in the sociospatial construction of the city. The perspective is not closed at these levels, as it could be enriched by still more levels, which enrich the multidimensionality of the territory's subsequent organizing concept.

In terms of urban geography, this approach represents a way to transcend the material basis derived from spatial forms, as well as partial conceptions of territory fed, above all, by the locational dimension. Therefore, for urban geography such an approach throws down the challenge to see things inside out: instead of accepting a city's spatial forms as products inherent to the society that shapes it, the starting point here is the subjects, who configure themselves into who they are in relation to their lived territory and their constant activity within it. Even when spatial practices are banal, subjects personalize them, fill them with social meanings, abandon them, dispute them, mark them, expand and contract them, relive the past in them, and also launch them into the future. Seeing things inside out also implies shifting temporality in terms of historic processes to everyday temporalities in which historicity and memory emerge, to be either reaffirmed or transformed. In other words, this social construction of the city's lived territory undertaken every day by its inhabitants can throw light on hidden corners of the city that remain undetected by analyses of the social production of urban space. Any urban geography that integrates these analytical dimensions (which are explored in other social sciences, although not always with a spatial emphasis) is fully capable of participating in the major debates of current social theory and enriching them from territorial perspectives.

Data availability. This article is based on the research project "Habitar la ciudad: La corporeidad y las emociones en clave espacial y biográfica", which was conducted in the Research Area of the Department of the Sociology of Universidad Autónoma Metropolitana, Campus Iztapalapa, Mexico City.

Competing interests. The author declares that she has no conflict of interest.

Acknowledgements. The author would like to thank the editors of the special issue "Contested Urban Territories: Decolonized Perspectives", Anke Schwarz and Monika Streule, for their constructive comments and thoughts.

Edited by: Myriam Houssay-Holzschuch

Reviewed by: two anonymous referees

\section{References}

Adams, P., Hoelscher, S., and Till, K.: Textures of Places: Exploring Humanist Geographies, University of Minnesota Press, Minneapolis, 2001.

Anderson, B.: Affective atmospheres, Emot. Space Soc., 2, 77-81, https://doi.org/10.1016/j.emospa.2009.08.005, 2009.

Anderson, B. and Harrison, P.: Taking-Place: Non-Representational Theories and Geography, Routledge, London, 2010.

Buttimer, A.: Grasping the dynamism of lifeworld, Annals of AAG, 66, 277-292, https://doi.org/10.1111/j.14678306.1976.tb01090.x, 1976.

Castoriadis, C.: The Imaginary Institution of Society, MIT Press, Cambridge, Mass., 1987.

Clough, P.: (De)Coding the Subject-in-Affect, Subjectivity, 23, 140-155, 2008.

Di Méo, G.: L'Homme, la société, l'espace, Anthropos, Paris, 1991.

Di Méo, G.: Géographies tranquilles du quotidien. Une analyse de la contribution des sciences sociales et de la géographie à l'étude des pratiques spatiales, Cahiers de Géographie du Québec, 43, 75-93, https://doi.org/10.7202/022788ar, 1999.

Di Méo, G.: Territoires des acteurs, territoires de l'action, BSGLg, 48, 7-17, 2006.

Di Méo, G.: Une géographie sociale entre représentations et action, Montagnes méditerranéennes et developpement territorial, 23, 13-21, 2008.

Di Méo, G. and Buleón, P.: L'espace social: Lecture géographique des sociétés, Armand Colin, Paris, 2005.

Goffman, E.: Frame Analysis. Los marcos de la experiencia, Centro de Investigaciones Sociológicas, Madrid, 2006.

Lave, J.: The culture of acquisition and the practice of understanding, in: Situated cognition: Social, semiotic and psychological 
perspectives, edited by: Kirshner, D. and Whitson, J., Lawrence Erlbaum Assoc., New Jersey, 17-35, 1997.

Lefebvre, H.: La production de l'espace, Anthropos, Paris, 1974.

Lindón, A.: El imaginario suburbano: entre los sueños diurnos y la reproducción socio-espacial de la ciudad, Iztapalapa RCSH, 64, 39-62, 2008.

Lindón, A.: Territorialized everydayness between proxemics and diastemics: space-time rhythms in a context of acceleration, in: Body and time: bodily rhythms and social rhythms and Social Synchronism in the Digital Media Society, edited by: Pirani, B. and Smith, T., Cambridge Scholars Publishing, Cambridge, 83105, 2013.

Lindón, A.: Del cronotopo fundacional a la construcción socioespacial del territorio vallechalquense, in: La periferia metropolitana: entre la ciudad prometida y un lugar para vivir en la ciudad de México, edited by: Lindón, A. and Mendoza, C., GedisaUAMI, Mexico, 115-150, 2015.

Lussault, M. and Stock, M.: "Doing with space": towards a pragmatics of space, Soc. Geogr., 5, 11-19, https://doi.org/10.5194/sg-5-11-2010, 2010.

Merleau-Ponty, M.: Phenomenology of Perception, Routledge \& Kegan Pau, London, 1962.

Michels, C.: Researching affective atmospheres, Geogr. Helv., 70, 255-263, https://doi.org/10.5194/gh-70-255-2015, 2015.

Pile, S.: The Body and the City: Psychoanalysis, Space and Subjectivity, Routledge, London, 1996.

Pintos Peñaranda, M. F.: Fenomenología de la corporeidad emotiva como condición de la alteridad, Investigaciones Fenomenológicas, 2, 141-168, 2010.
Pred, A.: The Choreography of Existence: Comments on Hägerstrand's Time-Geography and Its Usefulness, Econ. Geogr., 53, 207-221, https://doi.org/10.2307/142726, 1977.

Pred, A.: Social Reproduction and the Time-Geography of Everyday Life, Geogr. Ann. B, 63, 5-22, https://doi.org/10.2307/490994, 1981.

Raffestin, C.: Écogénèse territoriale et territorialité, in: Espaces, jeux et enjeux, edited by: Auriac, F. and Brunet, R., Fayard, Paris, 175-185, 1986.

Seamon, D.: Body-Subject, Time-Space Routines, and PlaceBallets, in: The Human Experience of Space and Place, edited by: Buttimer, A. and Seamon, D., Croom Helm, London, 148$165,1980$.

Silva, A.: Imaginarios urbanos, Tercer Mundo Editores, Bogotá, 1992.

Silva, A.: Imaginarios urbanos: hacia el desarrollo de un urbanismo desde los ciudadanos, Universidad Nacional de Colombia, Bogotá, 2006.

Simonsen, K.: Practice, spatiality and embodied emotions: A outline of a geography of practice, Human Affairs, 17, 168-181, https://doi.org/10.2478/v10023-007-0015-8, 2007.

Thrift, N.: Steps to an Ecology of Place, in: Human Geography Today, edited by: Massey D., Allen J., and Sarre, P., Polity Press, Cambridge, 295-323, 1999.

Thrift, N.: Non-representational theory: space, politics, affect, Routledge, London, New York, 2008.

Turner, V.: Dramas, Fields, and Metaphors: Symbolic Action in $\mathrm{Hu}-$ man Society, Cornell University Press, New York, 1974.

Werlen, B.: Society, Action and Space: An Alternative Human Geography, Routledge, London, 1992. 